\title{
Hubungan Sulit Makan Pangan Hewani, Tingkat Asupan Energi, Asam Folat, Dan Seng Dengan Perkembangan Motorik Halus Dan Motorik Kasar Anak Prasekolah Di Tk Kristen Setabelan Surakarta
}

\section{Association between Eating Difficulty on Animal Based Foods, Energy, Folic Acid, and Zinc Intake with Fine and Gross Motor Development among Preschoolers In Setabelan Christian Kindergarten Of Surakarta}

Hana Dwi Prastika*, Sri Sumarmi

ABSTRAK

Latar Belakang: Perkembangan motorik adalah perkembangan unsur kematangan pengendalian gerak tubuh yang berkaitan dengan perkembangan pusat motorik di otak. Sulit makan pangan hewani merupakan salah satu alasan terjadinya defisiensi zat gizi yang dibutuhkan dalam perkembangan anak, khususnya perkembangan motoriknya.

Tujuan: Penelitian ini bertujuan untuk menganalisis hubungan sulit makan pangan hewani, tingkat asupan energi, asam folat, dan seng dengan perkembangan motorik halus dan motorik kasar pada anak prasekolah di TK Kristen Setabelan Surakarta usia 4 tahun.

Metode: Penelitian dengan desain cross sectional dilaksanakan di TK Kristen Setabelan Surakarta. Populasinya seluruh murid TK Kristen Setabelan Surakarta berusia 4 tahun sebanyak 48 siswa. Pengambilan sampel menggunakan simple random sampling dengan rumus Slovin, didapatkan 33 subyek penelitian. Variabel penelitian yaitu sulit makan pangan hewani, tingkat asupan energi, asam folat, dan seng sebagai variabel bebas dan perkembangan motorik halus dan motorik kasar sebagai variabel terikat. Data primer dikumpulkan dengan wawancara dengan bantuan kuesioner. Analisis data menggunakan uji statistik Chi Square dan Spearman.

Hasil: Analisa uji Chi Square menunjukkan ada kaitan antara sulit makan pangan hewani dengan perkembangan motorik halus dan motorik kasar anak prasekolah dengan nilai $p<0,05$. Analisa uji Spearman menunjukkan ada kaitan antara tingkat asupan energi, asam folat, dan seng dengan perkembangan motorik halus dan motorik kasar anak prasekolah dengan nilai $\mathrm{p}$ $<0,05$.

Kesimpulan: Terdapat hubungan antara sulit makan pangan hewani, tingkat asupan energi, asam folat, dan seng dengan perkembangan motorik halus dan motorik kasar anak prasekolah.

Kata kunci: sulit makan, pangan hewani, energi, protein, zat besi, perkembangan motorik

\section{ABSTRACT}

Background: Motor development is the development of a child's ability to control their movement and closely related to the development of the motor center in the brain. Difficulty eating animal based foods can cause nutritional deficiencies which negatively impact a child's development, especially motor development.

Objectives: This study aimed to analyze the correlation between eating difficulty animal based foods, energy, folic acid, and zinc intake with fine and gross motor development in preschoolers aged 4 in Setabelan Christian Kindergarten of Surakarta.

Methods: This was observational study with cross sectional design. The population was all the preschoolers aged 4 years old. Sample was determined using simple random sampling technique with Slovin's formula and 33 research subjects included in this study. The research variables were eating difficulty on animal based foods, energy, folic acid, and zinc intake as independent variables and motor development in preschoolers as dependent variable. Statistical analysis used was Chi Square and Spearman statistic in this research.

Results: Based on Chi square statistic showed there was a correlation between eating difficulty on animal based foods with motor development of preschoolers with value of $p<0.05$. Spearman test results showed there were relationships between energy, folic acid, and zinc intake with motor development of preschoolers with value of $p<0.05$. 
Conclusions: There were relationships between eating difficulty on animal based foods, energy, folic acid, and zinc intake with fine motor development of preschoolers.

Keywords: eating difficulty, animal based foods, energy, folic acid, zinc, motor development

\author{
*Koresponden: \\ Hana Dwi Prastika \\ hanaprastika92@gmail.com \\ Departemen Gizi Kesehatan, Fakultas Kesehatan Masyarakat, Universitas Airlangga \\ Kampus C Mulyorejo, 60115, Surabaya, Jawa Timur, Indonesia
}

\section{PENDAHULUAN}

Masa 5 tahun pertama kehidupan pertumbuhan dan perkembangan anak sering disebut masa emas karena pada masa itu keadaan fisik dan kemampuan anak sedang berkembang dengan pesatnya. Secara fisik, anak juga akan terlihat lebih tinggi dan lebih besar. Pada usia Taman Kanak-Kanak (TK) perkembangan kemampuan anak juga akan sangat terlihat. Salah satu kemampuan yang sedang berkembang dengan pesat di usia Taman Kanak-Kanak adalah kemampuan fisik dan motoriknya. Perkembangan motorik adalah perkembangan unsur kematangan pengendalian gerak tubuh yang erat kaitannya dengan perkembangan pusat motorik di otak. Perkembangan motorik erat kaitannya dengan kematangan syaraf dan otot. Setiap gerakan, sesederhana apapun gerakan yang dilakukan merupakan hasil pola antar hubungan yang kompleks dari berbagai bagian sistem dalam tubuh yang dikontrol oleh otak ${ }^{1}$.

Kasus keterlambatan perkembangan motorik sebanyak $50 \%$ di Asia, di Afrika sebanyak 30\%, dan $20 \%$ terjadi pada anak-anak di Amerika Latin. Hasil penelitian yang fokus pada perkembangan motorik anak balita menjelaskan bahwa keterlambatan perkembangan motorik sebanyak $49 \%$, yang dikarenakan kurangnya pengetahuan ibu dan terjadi di negara berkembang ${ }^{2}$. Lebih dari sepertiga balita (70 juta) dari 200 juta balita di negara-negara berkembang tidak terasah kemampuannya untuk perkembangan ${ }^{3}$. Masalah tumbuh kembang anak yang tidak normal yang terjadi di masyarakat begitu beragam, seperti contohnya dapat dikaji 10 macam masalah yang terbanyak ditemukan pada penderita baru yang melakukan rawat jalan di klinik Tumbuh Kembang RS Dr.Soetomo tahun 2005. Keterlambatan perkembangan motorik (motoric delay) menjadi kasus terbanyak nomor 3 setelah developmental delay dan speech delay dari 10 kasus terbanyak ${ }^{4}$.

Sulit makan merupakan salah satu alasan terjadinya defisiensi zat gizi yang dibutuhkan dalam perkembangan anak, khususnya perkembangan motoriknya. Usia prasekolah adalah masa transisi dari kondisi di mana seorang anak yang pada awalnya lebih sering menerima makanan yang diberikan oleh ibunya kepada keadaan di mana anak sudah bisa memilih sendiri makanan yang disukainya ${ }^{5}$. Dalam masa ini anak mengalami perubahan pola makan dimana biasanya anak menjadi sulit makan. Perkembangan yang khas dari perilaku anak pra sekolah ini mempengaruhi pola makan anak. Anak menjadi terlalu pemilih terhadap makanan. Anak usia 3 hingga 4 tahun (prasekolah), memulai fase negativistik yaitu tidak mau makan karena menunjukkan keakuannya. Selalu menolak makanan dan seringkali susah makan karena mereka lebih senang bermain ${ }^{6}$.

Status gizi yang baik akan menjaga tubuh anak dari berbagai penyakit. Asupan zat gizi yang tidak optimal menyebabkan adanya defisiensi zat gizi yang menyebabkan gangguan pertumbuhan dan perkembangan anak pra sekolah. Kondisi kurangnya asupan gizi tidak hanya berdampak pada status gizi tetapi juga pada perkembangan anak khususnya perkembangan motorik anak. Sulit makan pangan hewani dapat mengakibatkan asupan zat gizi yang tidak optimal khususnya asupan energi, seng, dan asam folat yang dibutuhkan untuk mendukung perkembangan motorik anak prasekolah.

Berdasarkan penelitian sebelumnya yang dilakukan di Posyandu Buah Hati Ketelan Banjarsari Surakarta, menunjukkan bahwa persentase anak yang perkembangan motoriknya di bawah normal lebih tinggi pada anak yang asupan zat gizinya kurang dibanding pada anak dengan asupan gizi cukup ${ }^{7}$. Riset lain menunjukkan bahwa 35,3\% anak prasekolah di TK Al Firdaus Surakarta terdeteksi mengalami perkembangan motorik yang tidak normal dan anak yang mengalami perkembangan motorik yang tidak normal tersebut terjadi pada anak yang mengalami defisiensi gizi ${ }^{8}$. Berdasarkan uraian latar belakang tersebut, penulis ingin melaksanakan riset tentang hubungan sulit makan pangan hewani, tingkat asupan asam folat, dan seng dengan perkembangan motorik anak prasekolah di TK Kristen Setabelan Surakarta.

\section{METODE}

Penelitian ini telah lulus uji etik dari Fakultas Kedokteran Gigi Universitas Airlangga dengan nomor sertifikat 148/HRECC.FODM/IV/2019. Jenis penelitian observasional dengan disain cross sectional. Populasinya meliputi seluruh murid usia 4 tahun yang bersekolah di TK Kristen Setabelan Surakarta sebanyak 48 siswa. Besar sampel ditentukan dengan menggunakan rumus Slovin. Pengambilan sampel dihitung dengan rumus Slovin dan didapatkan hasil sebanyak 33 siswa. Penentuan sampel dengan metode simple random sampling yang mana tiap anggota populasi mempunyai peluang yang sama untuk menjadi sampel penelitian. Pemilihan sampel menggunakan lottery technique. Responden penelitian adalah orangtua murid yang dijadikan subyek penelitian. Lokasi penelitian di TK Kristen Setabelan Surakarta. Penelitian dilakukan pada bulan April 2019. Variabel 
bebas dari penelitian ini adalah sulit makan pangan hewani, tingkat asupan energi, asam folat, dan seng. Variabel terikatnya yaitu perkembangan motorik anak prasekolah.

Penelitian ini menggunakan data primer dan data sekunder. Data primer didapatkan melalui hasil wawancara langsung dengan menggunakan instrumen formulir Food Recall 24 jam dan pengisian kuesioner. Kuesioner yang digunakan berisi pertanyaan tentang biodata, latar belakang responden dan anak prasekolah. Wawancara dilakukan dengan bertatapan muka langsung kepada responden dengan mengajukan pertanyaan-pertanyaan yang ada pada kedua formulir. Wawancara langsung yang menggunakan Food Recall 24 jam bertujuan untuk melihat berapa banyaknya makanan yang dimakan kemudian dapat dihitung konsumsi zat gizinya. Wawancara yang dilakukan dengan form Food Recall 24 jam dilaksanakan 2 × 24 jam dalam arti dilakukan dua kali di hari yang berbeda dan harinya tidak berurutan. Data sekunder meliputi pengambilan daftar nama murid.

Pengukuran perkembangan motorik anak dilakukan dengan observasi langsung kepada anak prasekolah dengan instrumen DDST (Denver Developmental Screening Test) atau Denver II. Pengukuran per item tugas yang harus dikerjakan anak prasekolah dilaksanakan dengan stimulus berupa ajakan bermain bersama.

Data yang telah diperoleh dari hasil penelitian diolah dengan program SPSS, tahap yang dilakukan sebelum analisis yaitu editing dan tabulasi. Tahap editing meliputi pengumpulan data yang dipastikan telah terjawab dan jawaban telah sesuai dengan maksud dari pertanyaan yang dimaksudkan oleh peneliti. Tahap tabulasi yaitu membuat tabulasi atau memproses data, merupakan suatu kegiatan memasukkan data ke dalam tabel-tabel sehingga mudah dihitung dan dibaca. Data yang telah diperoleh akan dikumpulkan kemudian dianalisis dengan menggunakan perangkat lunak komputer. Setelah itu dilakukan uji dengan metode statistik menggunakan uji Chi Square untuk menguji korelasi sulit makan pangan hewani dengan perkembangan motorik halus dan motorik kasar anak prasekolah dan uji Spearman untuk menguji korelasi tingkat asupan energi, asam folat, dan seng dengan perkembangan motorik halus dan motorik kasar anak prasekolah.

\section{HASIL DAN PEMBAHASAN}

Berdasarkan hasil penelitian, dari 33 subyek penelitian terdapat 18 anak (54,5\%) yang terdeteksi sulit makan pangan hewani. Preferensi makanan anak prasekolah nampak pada makanan yang kaya karbohidrat yang mudah dikunyah. Sereal, roti, dan kraker sering dipilih daripada daging dan makanan tinggi protein lainnya. Masalah sulit makan yang biasa ditemukan pada anak-anak seperti pilih-pilih makanan, takut akan makanan tertentu (neophobia), mengikuti tren tertentu (faddy), dan kegemukan (obesitas). Selain itu anak-anak juga sering tidak mau mencoba makanan baru atau menolak makanan yang tidak mereka kenal sebelumnya meskipun dalam kenyataannya makanan tersebut menyehatkan. Mereka cenderung mengelompokkan makanan dengan pernyataan suka dan tidak suka. Preferensi makanan pada anak prasekolah secara keseluruhan tidak sejalan dengan makanan sehat ${ }^{9}$.

Anak prasekolah dengan sulit makan pangan hewani sebagian besar mengalami perkembangan motorik yang abnormal, baik pada perkembangan motorik halus maupun pada motorik kasar. Hasil penghitungan uji statistik Chi Square didapatkan hasil $P$ value sebesar 0,009 dan 0.036 (Tabel 1) yang berarti bahwa terdapat hubungan antara sulit makan pangan hewani dengan perkembangan motorik halus dan motorik kasar anak prasekolah. Teori yang dikemukakan oleh Soetjiningsih (2013) menyatakan bahwa sulit makan pada anak memberikan dampak yang tidak hanya pada kesehatan namun juga pada tumbuh kembang anak. Hal yang ditimbulkan karena perilaku sulit makan adalah malnutrisi yang mengakibatkan defisiensi berbagai macam mineral, vitamin, dan protein sehingga akan menurunkan daya tahan tubuh termasuk fungsi imun yang selanjutnya dapat menurunkan kualitas individu ${ }^{10}$. Sejalan dengan riset yang dilakukan oleh Xue (2015), menyatakan bahwa anak yang sulit makan lebih berpeluang memiliki asupan energi, protein, karbohidrat, vitamin, dan mineral yang lebih rendah. Perilaku sulit makan khususnya terhadap pangan hewani menyebabkan gangguan pembentukan mineral tulang yang dalam kenyataannya perkembangan motorik membutuhkan kerja otot serta tulang untuk menopang aktivitas fisik anak prasekolah yang meningkat ${ }^{11}$.

Tabel 1 Hubungan Sulit Makan Pangan Hewani dengan Perkembangan Motorik Anak Prasekolah

\begin{tabular}{|c|c|c|c|c|c|c|c|c|c|}
\hline \multirow{3}{*}{\multicolumn{2}{|c|}{ Sulit Makan }} & \multicolumn{8}{|c|}{ Perkembangan Motorik } \\
\hline & & \multicolumn{2}{|c|}{ Motorik Halus } & \multirow{2}{*}{ Total } & \multirow{2}{*}{ P Value } & \multicolumn{2}{|c|}{ Motorik Kasar } & \multirow{2}{*}{ Total } & \multirow{2}{*}{ P Value } \\
\hline & & Normal & Abnormal & & & Normal & Abnormal & & \\
\hline \multirow[t]{2}{*}{ Tidak } & $\mathrm{n}$ & 11 & 4 & 15 & \multirow{6}{*}{0,009} & 8 & 7 & 15 & \multirow{6}{*}{0,036} \\
\hline & $\%$ & 33,3 & 12,1 & 45,4 & & 24,2 & 21,2 & 45,4 & \\
\hline \multirow[t]{2}{*}{$\mathrm{Ya}$} & $\mathrm{n}$ & 5 & 13 & 18 & & 6 & 12 & 18 & \\
\hline & $\%$ & 15,1 & 39,4 & 54,5 & & 18,2 & 36,4 & 54,6 & \\
\hline \multirow[t]{2}{*}{ Total } & $\mathrm{n}$ & 16 & 17 & 33 & & 14 & 19 & 33 & \\
\hline & $\%$ & 48,4 & 51,5 & 100 & & 42,4 & 57,5 & 100 & \\
\hline \multicolumn{6}{|c|}{$\begin{array}{l}\text { Sebagian besar anak prasekolah memiliki } \\
\text { tingkat asupan energi yang masih kurang dari Angka } \\
\text { Kecukupan Gizi (AKG) yang dapat dilihat pada Tabel } 2 \text {. } \\
\text { Anak prasekolah yang memiliki tingkat asupan energi }\end{array}$} & \multicolumn{4}{|c|}{$\begin{array}{l}\text { yang kurang dari AKG memiliki peluang lebih besar } \\
\text { mengalami perkembangan motorik yang abnormal, baik } \\
\text { pada perkembangan motorik halus maupun pada }\end{array}$} \\
\hline
\end{tabular}


didapatkan nilai $P$ Value sebesar 0,025 yang mengindikasikan bahwa terdapat hubungan antara tingkat asupan energi dengan perkembangan motorik halus anak prasekolah. Begitu juga pada perkembangan motorik kasar anak prasekolah, penghitungan dengan uji Spearman didapatkan $P$ Value 0,036 yang menunjukkan bahwa terdapat hubungan antara tingkat asupan energi dengan perkembangan motorik kasar anak prasekolah ${ }^{12}$. Teori yang dikemukakan oleh Prado et al (2014) menyatakan bahwa energi berperan dalam perkembangan otak, seperti pembentukan dan pertumbuhan akson dan dendrit, formasi sinapsis, dan fase mielinisasi secara keseluruhan. Apabila tubuh kekurangan energi, maka proses perkembangan syaraf pusat akan terganggu sehingga impuls atau rangsangan untuk melakukan suatu gerak motorik akan bermasalah ${ }^{13}$.

Tabel 2 Hubungan Tingkat Asupan Energi dengan Perkembangan Motorik Anak Prasekolah

\begin{tabular}{|c|c|c|c|c|c|c|c|c|c|c|c|}
\hline \multirow{4}{*}{$\begin{array}{c}\text { Tingkat } \\
\text { Asupan } \\
\text { Energi }\end{array}$} & \multicolumn{11}{|c|}{ Perkembangan Motorik } \\
\hline & \multirow{2}{*}{\multicolumn{3}{|c|}{$\begin{array}{c}\text { Motorik } \\
\text { Halus }\end{array}$}} & \multirow{3}{*}{ Total } & \multirow{3}{*}{$\begin{array}{c}P \\
\text { Value }\end{array}$} & \multirow{3}{*}{ Rs } & \multirow{2}{*}{\multicolumn{2}{|c|}{$\begin{array}{c}\text { Motorik } \\
\text { Kasar }\end{array}$}} & \multirow{3}{*}{ Total } & \multirow{3}{*}{$\begin{array}{c}\mathrm{P} \\
\text { Value }\end{array}$} & \multirow{3}{*}{ Rs } \\
\hline & & & & & & & & & & & \\
\hline & & Normal & $\begin{array}{c}\text { Abnor- } \\
\text { mal }\end{array}$ & & & & Normal & $\begin{array}{c}\text { Abnor- } \\
\text { mal }\end{array}$ & & & \\
\hline \multirow[t]{2}{*}{ Baik } & $\mathrm{n}$ & 8 & 2 & 10 & \multirow{8}{*}{0,025} & \multirow{8}{*}{0,390} & 7 & 3 & 10 & \multirow{8}{*}{0,036} & \multirow{8}{*}{0,366} \\
\hline & $\%$ & 24,2 & 6,1 & 30,3 & & & 21,2 & 9,1 & 30,3 & & \\
\hline \multirow[t]{2}{*}{ Sedang } & $\mathrm{n}$ & 2 & 3 & 5 & & & 2 & 3 & 5 & & \\
\hline & $\%$ & 6,1 & 9,0 & 15,1 & & & 6,1 & 9,1 & 15,2 & & \\
\hline \multirow[t]{2}{*}{ Kurang } & $\mathrm{n}$ & 6 & 12 & 18 & & & 5 & 13 & 18 & & \\
\hline & $\%$ & 18,2 & 36,4 & 54,6 & & & 15,1 & 39,4 & 54,5 & & \\
\hline \multirow[t]{2}{*}{ Total } & $\mathrm{n}$ & 16 & 17 & 33 & & & 14 & 19 & 33 & & \\
\hline & $\%$ & 48,5 & 51,5 & 100 & & & 42,4 & 57,6 & 100 & & \\
\hline
\end{tabular}

Asam folat memegang peranan penting dalam proses perkembangan motorik anak. Sama seperti peran vitamin B yang lainnya, asam folat berfungsi dalam perkembangan saraf. Pada Tabel 3 dapat diketahui bahwa mayoritas anak prasekolah memiliki asupan asam folat yang masih kurang dari AKG. Anak prasekolah dengan tingkat asupan asam folat yang kurang berpeluang lebih banyak mengalami perkembangan motorik yang tidak normal, baik itu pada perkembangan motorik halus maupun pada motorik kasar. Analisis uji statistik Spearman didapatkan nilai $P$ Value sebesar 0,008 yang menunjukkan bahwa terdapat korelasi antara tingkat asupan asam folat dengan perkembangan motorik halus anak prasekolah. Begitu juga dengan motorik kasar anak prasekolah yang ada hubungannya dengan tingkat asupan asam folatnya ( $P$ Value $=0,007$ ). $\mathrm{Hal}$ ini sejalan dengan riset yang dijalankan oleh Kvestad (2015) bahwa anak yang diberi suplementasi asam folat dan B12 memiliki perkembangan motorik yang lebih baik daripada anak yang tidak diberi suplementasi ${ }^{14}$.

Tabel 3 Hubungan Tingkat Asupan Asam Folat dengan Perkembangan Motorik Anak Prasekolah

\begin{tabular}{|c|c|c|c|c|c|c|c|c|c|c|c|}
\hline \multirow{3}{*}{\multicolumn{2}{|c|}{$\begin{array}{l}\text { Tingkat Asupan } \\
\text { Asam Folat }\end{array}$}} & \multicolumn{10}{|c|}{ Perkembangan Motorik } \\
\hline & & \multicolumn{2}{|c|}{ Motorik Halus } & \multirow[b]{2}{*}{ Total } & \multirow{2}{*}{$\begin{array}{c}P \\
\text { Value }\end{array}$} & \multirow[b]{2}{*}{ Rs } & \multicolumn{2}{|c|}{ Motorik Kasar } & \multirow[b]{2}{*}{ Total } & \multirow{2}{*}{$\begin{array}{c}\mathrm{P} \\
\text { Value }\end{array}$} & \multirow[b]{2}{*}{ Rs } \\
\hline & & Normal & $\begin{array}{l}\text { Abnor- } \\
\text { mal }\end{array}$ & & & & Normal & $\begin{array}{l}\text { Abnor- } \\
\text { mal }\end{array}$ & & & \\
\hline \multirow[t]{2}{*}{ Baik } & $\mathrm{n}$ & 7 & 1 & 8 & \multirow{8}{*}{0,008} & \multirow{8}{*}{0,456} & 5 & 3 & 8 & \multirow{8}{*}{0,007} & \multirow{8}{*}{0,461} \\
\hline & $\%$ & 21,2 & 3,0 & 24,2 & & & 15,1 & 9,1 & 24,2 & & \\
\hline \multirow[t]{2}{*}{ Sedang } & $\mathrm{n}$ & 4 & 4 & 8 & & & 6 & 2 & 8 & & \\
\hline & $\%$ & 12,1 & 12,1 & 24,2 & & & 18,2 & 6,1 & 24,3 & & \\
\hline \multirow[t]{2}{*}{ Kurang } & $\mathrm{n}$ & 5 & 12 & 17 & & & 3 & 14 & 17 & & \\
\hline & $\%$ & 15,1 & 36,4 & 51,5 & & & 9,1 & 42,4 & 51,5 & & \\
\hline \multirow[t]{2}{*}{ Total } & $\mathrm{n}$ & 16 & 17 & 33 & & & 14 & 19 & 33 & & \\
\hline & $\%$ & 48,4 & 51,5 & 100 & & & 42,4 & 57,6 & 100 & & \\
\hline
\end{tabular}

Tabel 4 menunjukkan bahwa mayoritas anak prasekolah memiliki tingkat asupan seng yang masih kurang dari AKG. Anak prasekolah dengan tingkat asupan seng yang kurang sebagian besar mengalami perkembangan motorik halus dan motorik kasar yang abnormal. Hasil penelitian ini selaras dengan hasil penelitian yang dilakukan oleh Ardiaria (2014) yang menunjukkan ada hubungan yang positif antara seng dengan perkembangan motorik anak. Anak yang tingkat asupan sengnya rendah mempunyai skor fungsi motorik yang rendah. Begitu juga dengan anak yang tingkat asupan sengnya tinggi maka pencapaian skor fungsi motoriknya juga tinggi ${ }^{15}$. Seng diperlukan untuk proses pembelahan dan peningkatan kemampuan membran sel-sel serta bersinergi dalam tahap penyatuan protein yang berimbas langsung pada regenerasi sel. Apabila tubuh mengalami defisiensi sel maka pembentukan otot akan terhambat.

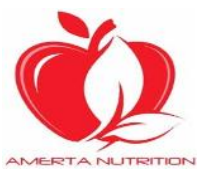


Tabel 4 Hubungan Tingkat Asupan Seng dengan Perkembangan Motorik Anak Prasekolah

\begin{tabular}{|c|c|c|c|c|c|c|c|c|c|c|c|}
\hline \multirow{3}{*}{\multicolumn{2}{|c|}{$\begin{array}{c}\text { Tingkat Asupan } \\
\text { Seng }\end{array}$}} & \multicolumn{10}{|c|}{ Perkembangan Motorik } \\
\hline & & \multicolumn{2}{|c|}{ Motorik Halus } & \multirow[b]{2}{*}{ Total } & \multirow{2}{*}{$\begin{array}{c}\mathrm{P} \\
\text { Value }\end{array}$} & \multirow[b]{2}{*}{ Rs } & \multicolumn{2}{|c|}{ Motorik Kasar } & \multirow[b]{2}{*}{ Total } & \multirow{2}{*}{$\begin{array}{c}\mathrm{P} \\
\text { Value }\end{array}$} & \multirow[b]{2}{*}{ Rs } \\
\hline & & Normal & $\begin{array}{c}\text { Abnor- } \\
\text { mal }\end{array}$ & & & & Normal & $\begin{array}{c}\text { Abnor- } \\
\text { mal }\end{array}$ & & & \\
\hline \multirow[t]{2}{*}{ Baik } & $\mathrm{n}$ & 11 & 5 & 16 & \multirow{8}{*}{0,007} & \multirow{8}{*}{0,463} & 10 & 6 & 16 & \multirow{8}{*}{0,004} & \multirow{8}{*}{0,483} \\
\hline & $\%$ & 33,3 & 15,1 & 48,4 & & & 30,3 & 18,2 & 48,5 & & \\
\hline \multirow[t]{2}{*}{ Sedang } & $\mathrm{n}$ & 3 & 2 & 5 & & & 3 & 2 & 5 & & \\
\hline & $\%$ & 9,1 & 6,1 & 15,2 & & & 9,1 & 6,1 & 15,2 & & \\
\hline \multirow[t]{2}{*}{ Kurang } & $\mathrm{n}$ & 2 & 10 & 12 & & & 1 & 11 & 12 & & \\
\hline & $\%$ & 6,1 & 30,3 & 36,4 & & & 3,0 & 33,3 & 36,3 & & \\
\hline \multirow[t]{2}{*}{ Total } & $\mathrm{n}$ & 16 & 17 & 33 & & & 14 & 19 & 33 & & \\
\hline & $\%$ & 48,5 & 51,5 & 100 & & & 42,4 & 57,6 & 100 & & \\
\hline
\end{tabular}

\section{KESIMPULAN}

Hasil riset menunjukkan bahwa terdapat hubungan antara sulit makan pangan hewani, tingkat asupan energi, asam folat, dan seng dengan perkembangan motorik anak prasekolah. Saran dari penelitian ini adalah perlu adanya workshop atau pelatihan tentang gizi terhadap orangtua murid agar dapat menyediakan makanan dengan gizi seimbang supaya anak prasekolah tidak mengalami defisiensi zat gizi yang dibutuhkan dalam proses tumbuh kembangnya.

\section{ACKNOWLEDGEMENT}

Penulis berterimakasih kepada semua dosen dan staf Departemen Gizi, Fakultas Kesehatan Masyarakat, Universitas Airlangga atas arahan dan panduan yang diberikan kepada penulis.

\section{REFERENSI}

1. Sujiono, B., Sumantri, M. . \& Candrawati, T. Hakikat Perkembangan Motorik Anak. (Universitas Terbuka, 2008).

2. Jurana. Perkembangan Motorik Kasar dan Halus pada Anak Usia 1-3 Tahun (Toddler) di Kelurahan Mamboro Barat Wilayah Kerja Puskesmas Mamboro. Med. Tadulako J. IIm. Kedokt. 4, 47-63 (2017)

3. Christiari, A. Y., Syamlan, R. \& Kusuma, I. F. Hubungan Pengetahuan Ibu tentang Stimulasi Dini dengan Perkembangan Motorik pada Anak Usia 6-24 bulan di Kecamatan Mayang Kabupaten Jember. J. Pustaka Kesehat. 1, 20-23 (2013).

4. Irwanto, Suryawan, A. \& Narendra, M. B. Penyimpangan Tumbuh Kembang Anak. Div. Tumbuh Kembang Anak dan Remaja Bagian IImu Kesehat. Anak FK Unair RSU Dr. Soetomo Surabaya 6, 2-16 (2017).

5. Rosales, F. J., Reznick, J. S. \& Zeisel, S. H. Understanding the Role of Nutrition in the Brain
\& Behavioral Development of Toddlers and Preschool Children: Identifying and Overcoming Methodological Barriers. NIH Public Access 12, 190-202 (2009).

6. Ariani, A. P. Ilmu Gizi. (Nuha Medika, 2017)

7. Sari, D. W., Nur, E. \& Purwanto, S. Hubungan Antara Status Gizi Dengan Perkembangan. J. Fak. IImu Kesehat. Univ. Muhammadiyah Surakarta 5, 157-164 (2012).

8. Syahriani, A. Perbedaan Perkembangan Motorik Kasar Pada Anak Prasekolah Antara Pertumbuhan Kurang, Normal, dan Obesitas Di TK Al Firdaus Surakarta. Universitas Muhammadiyah Surakarta (2013).

9. Worthington-Roberts, B. \& William, S. Nutrition Throughout The Life Cycle. (The McGraw-Hill Companies, 2000).

10. Soetjiningsih \& Ranuh, I. N. G. Tumbuh Kembang Anak. (Buku Kedokteran EGC, 2013).

11. Xue, Y. et al. Prevalence of Picky Eating Behaviour in Chinese School-age Children and Associations with Anthropometric Parameters and Intelligence Quotient . A cross-sectional Study. Appetite 91, 248-255 (2015).

12. Emalia, Febry, F. \& Rahmiwati, A. Hubungan Asupan Gizi, Pengetahuan, dan Stimulasi Ibu Dengan Tumbuh Kembang Anak Prasekolah TK Handayani Dan TK Teratai 26 Ilir Kecamatan Bukit Kecil Palembang. Ilmu Kesehat. Masy. Univerisitas Sriwij. 6, 23-30 (2015).

13. Prado, E. L. \& Dewey, K. G. Nutrition and Brain Development in Early Life. Nutr. Rev. 72, 267284 (2014).

14. Kvestad, I. et al. Vitamin B12 and Folic Acid Improve Gross Motor and Problem-Solving Skills in Young North Indian Children : A Randomized Placebo-Controlled Trial. Plos One J. 10, 1-15 (2015).

15. Ardiaria, M. \& Nuryanto. Hubungan Status Gizi dan Asupan Besi dan Seng terhadap Fungsi Motorik Anak Usia 2-5 Tahun. JNH (Journal Nutr. Heal. 2, 1-8 (2014). 